\title{
Image Processing System for pH Classification Using Biosensors
}

\author{
Faiz Syaikhoni Aziz ${ }^{1}$ Sujito ${ }^{1,2, *}$ Aji Prasetya Wibawa ${ }^{1,2}$ I Made Wirawan ${ }^{2}$ \\ Aripriharta $^{1,2}$ Abdullah Iskandar Syah ${ }^{2}$ Tran Huy Duy ${ }^{3}$
}

\author{
${ }^{1}$ Electrical Engineering Postgraduate, Universitas Negeri Malang, Indonesia \\ ${ }^{2}$ Electrical Engineering Department, Universitas Negeri Malang, Indonesia \\ ${ }^{3}$ Electrical Engineering Department, Dalat University, Vietnam \\ ${ }^{*}$ Corresponding author. Email : sujito.ft@um.ac.id
}

\begin{abstract}
The biosensor in this study used a butterfly pea flower. Butterfly pea flowers require a classification system because the colors produced in detecting $\mathrm{pH}$ are similar. The method used in this research is using image processing to get the RGB value to be analyzed using the Raspberry Pi 4. The operation and results of the $\mathrm{pH}$ classification will be displayed on the TFT LCD. The hardware design is designed in a closed manner with LED lighting. The results of this research on the hardware function well because it can take the $\mathrm{pH}$ color of the biosensor with the lighting obtained from the LED. While the results of the classification system with 10 trial samples of mineral water, soft drinks, water, detergent, clothes perfume, and chemical solutions obtained an accuracy of $88.55 \%$. and can display on the TFT LCD.
\end{abstract}

Keywords: Images Processing, pH, Classification, Biosensors

\section{INTRODUCTION}

The increasing population of humans has resulted in the exploitation of natural resources. The impact of the exploitation of natural resources causes environmental pollution. Environmental pollution will have an impact on changes in $\mathrm{pH}$ value. The $\mathrm{pH}$ value plays an important role in human life and needs to be monitored for quality control of pharmaceutical, cosmetic and food products [1]. PH conditions in body fluids need to be monitored to determine the level of quality of body health [2]. The condition of $\mathrm{pH}$ as a parameter of water quality needs to be monitored for the survival of organisms such as drinking water consumption, monitoring pond water, aquarium water, or water in aquaculture ponds [3].

One of the latest innovations in controlling $\mathrm{pH}$ conditions by utilizing biosensors. A biosensor is a bioanalysis device which has a biomolecular layer connected to a transducer to generate an electronic signal [4]. According to researchers [5], the butterfly pea is a plant that can be used as a biosensor to detect $\mathrm{pH}$. Butterfly pea contains anthocyanin compounds that have benefits as an indicator of acid and alkaline titration [6]. Anthocyanin compounds can change color at a certain $\mathrm{pH}$ due to the presence of chromophore and autochrome groups.

In developing the use of butterfly pea to detect $\mathrm{pH}$, according to researchers [7], the color produced by butterfly pea as an indicator of acid-base has similarities between $\mathrm{pH}$ 1- $\mathrm{pH} 4$ pink, $\mathrm{pH}$ 5- $\mathrm{pH} 8$ blue, $\mathrm{pH}$ 9- $\mathrm{pH} 11$ colored. purple and $\mathrm{pH} 12-\mathrm{pH} 14$ is yellow. In a study [8], the color change to detect $\mathrm{pH}$ resulted from butterfly pea had similar color at $\mathrm{pH} 0.04-\mathrm{pH} 3.3, \mathrm{pH}$ 3.9- $\mathrm{pH}$ 6.7, $\mathrm{pH} 7.4-\mathrm{pH} 8.5, \mathrm{pH} 9.0-\mathrm{pH} 10.0$ and $\mathrm{pH}$ 11.5-pH12. 0. In research [9], it was found that the results of $\mathrm{pH}$ detection using butterfly pea produced similar color changes at $\mathrm{pH} 1-\mathrm{pH} 3, \mathrm{pH} 4-\mathrm{pH} 8, \mathrm{pH} 9$ $\mathrm{pH} 11$, and $\mathrm{pH} 12-\mathrm{pH} 14$.

Based on previous research on the similarity in color produced by butterfly pea in detecting $\mathrm{pH}$, this research will create a classification system that functions to obtain a more accurate $\mathrm{pH}$ value with image processing users. Research using image processing has been done by previous researchers. Researcher [10], used RGB color for the classification of buildings, agriculture, forest, and water. From this research, it is found that 
using RGB color has good accuracy. Researcher [11], used RGB color to classify the types of plastic bottles with testing data of 200 bottles. The results of the classification of the plastic bottles, RGB color, have an accuracy of $93.33 \%$. Researcher [12], used the RGB and HSV methods in the classification of mango fruit maturity. The results of the classification of fruit maturity are RGB colors that have an accuracy of $90.4 \%$ and HSV colors have an accuracy of $84.2 \%$. Researcher [13], used image processing and classification for urine analysis using RGB color features. The results of this study, the RGB color feature can classify urine with 10 parameters well.

Based on the advantages of previous research, this study will use the RGB color feature for $\mathrm{pH}$ color classification. The difference between this study and previous research is in the parameters used. Previous research used parameters of mango fruit maturity, type of plastic bottle, urine color, building, and water, while this study focused more on the classification of the $\mathrm{pH}$ color produced by the butterfly pea extract and the system displays the $\mathrm{pH}$ value on the TFT LCD.

\section{MATERIAL AND METHOD}

The purpose of this research is to create an image processing system for $\mathrm{pH}$ classification using a biosensor. There are 14 classifications in this study, from $\mathrm{pH} 1-\mathrm{pH}$ 14. To achieve these objectives requires a planned and systematic research materials and methods.

\subsection{Material}

The image processing system is built using Rapsberry Pi 4 as data processing which has 2GB RAM, OpenGL ES 3.0 graphics, $2.4 \mathrm{GHz}$ and 5.0 GHz IEEE 802.11ac wireless, Bluetooth 5.0 BLE, Gigabit Ethernet, 2 USB 3.0 ports; 2 USB 2.0 ports, 40 pin GPIO, Dual display $2 \times$ micro-HDMI ports [14]. The Logitech C2720 camera is a component for capturing $\mathrm{pH}$ colors on a 5 Mega Pixel resolution biosensor, has a microphone, and the maximum image display reaches 720p or HD [15]. TFT LCD to operate the system and display classification results. LED which functions for lighting so that the camera has good accuracy in reading RGB color values. 3D printed material used to print hardware from the system, measuring glass as a biosensor container. The 5 Volt DC power supply is used as a system resource for both the camera, raspberry pi 4, TFT LCD, and lighting from the LED lights.

\subsection{Method}

The research method used in the research of image processing systems for $\mathrm{pH}$ classification using biosensors is hardware design, system design, and system testing design.

\subsubsection{Hardware Design}

The image processing system in this study was designed in a closed manner using 3D printing so that light from outside does not enter. 3D printing is made based on the size and design of the tool that is simple and easy to operate. 3D printing produces good material, is not fragile and lightweight. There is a place for the TFT LCD which is designed to make it easier to operate the system. The distance between the camera and the sample is $2.5 \mathrm{~cm}$. the distance is designed as close as possible to maximize the accuracy of the camera in capturing images. The lighting from the LED is placed close to the camera to improve accuracy. Hardware design can be seen in figure 1 .

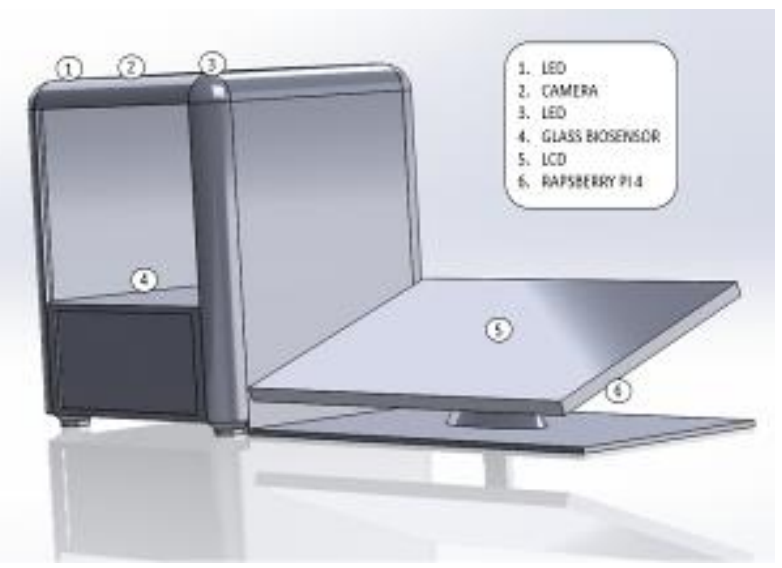

Figure 1 Hardware design

\subsubsection{System Design}

The design of this image processing system starts from the camera's $\mathrm{pH}$ color reader extracted by the Butterfly pea to get the RGB value feature. After taking the image, the colors will be extracted in the Red, Green, and Blue (RGB) color space by finding the average value through the equation below [16].

$$
\begin{aligned}
& \mathrm{R}=\frac{\mathrm{R}_{1}+\mathrm{R}_{2}+\mathrm{R}_{3}}{3} \\
& \mathrm{G}=\frac{\mathrm{G}_{1}+\mathrm{G}_{2}+\mathrm{G}_{3}}{3} \\
& \mathrm{~B}=\frac{\mathrm{B}_{1}+\mathrm{B}_{2}+\mathrm{B}_{3}}{3}
\end{aligned}
$$

After getting the RGB average value, the RGB value will be the feature value for each reference $\mathrm{pH}$ data and test $\mathrm{pH}$ data. To simplify the operation of this system after getting the $\mathrm{pH}$ value from the classification results. Then it will be displayed on the TFT LCD. The system planning flow diagram can be seen in figure 2 . 


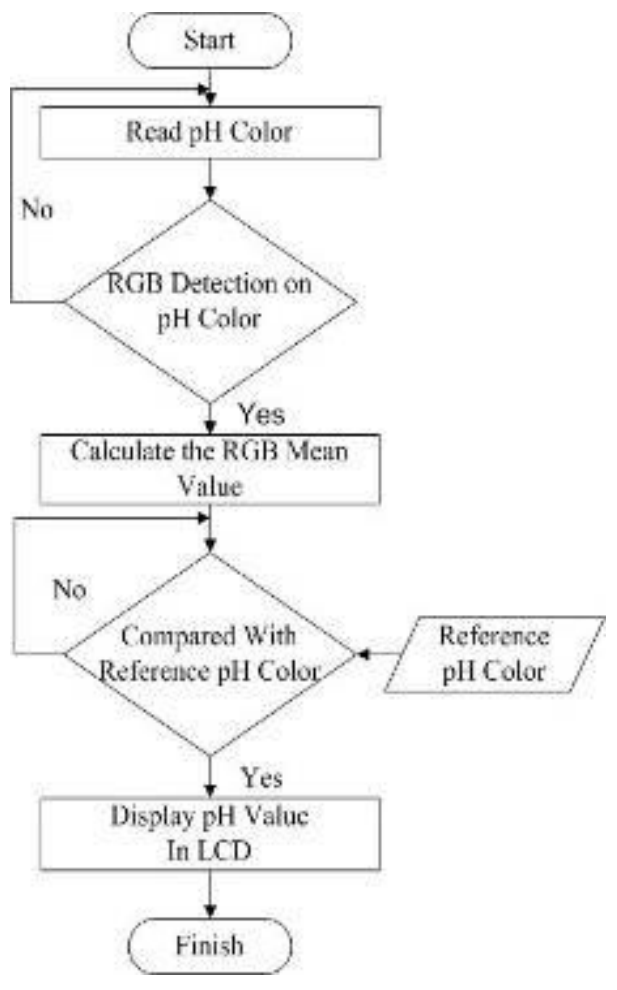

Figure 2 System design flowchart

\subsubsection{System Testing Design}

This system test is carried out to determine the performance of the image processing system for $\mathrm{pH}$ classification using a biosensor to function properly or not. System testing will be carried out in two stages. First hardware testing and second system testing. For system testing, the reading of the tool will be recorded and the percentage of its success will be calculated. To test the performance of the system in detecting $\mathrm{pH}$ levels, researchers used 10 samples from several mineral water products, soft drinks, water, detergents, clothes perfume, and chemical solutions to test their $\mathrm{pH}$ levels.

\section{RESULT AND DISCUSSION}

The image processing system is a $\mathrm{pH}$ classification system that is produced from a biosensor based on color parameters using a Logitech C270 camera and then processed with python programming on the Raspberry Pi 4. In the development process, there are two stages of testing to determine the performance of the system being developed, namely hardware testing and system testing.

\subsection{Hardware Testing Results}

Testing is done to validate the system so that it can be used properly. This test is carried out to ensure that the biosensor can be placed on the system so that it is easy to take pictures by the camera and that the lighting from the LED works properly so that the camera gets maximum results.7

This test is done by placing the biosensor onto the glass that is inserted into the system. This test serves to find the best accuracy for the biosensor layout and lighting function of the LED on the camera image results to the biosensor. The results of hardware testing can be seen in figure 3 .

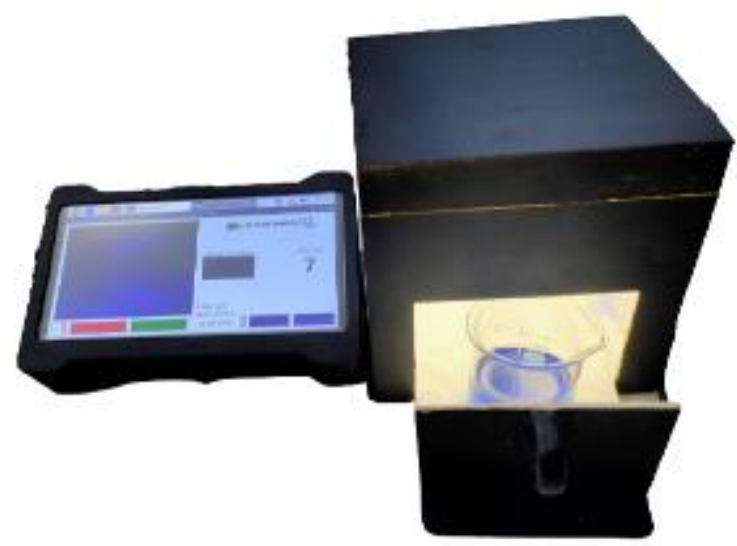

Figure 3 Hardware testing

From the test results, it is known that the camera can take biosensor images well with the help of the biosensor glass layout and the lighting is obtained from the LED. This can be seen in figure 3 colors captured by the camera with those shown on the LCD.

\subsection{System Testing Results}

The test is carried out to validate the image processing system in the $\mathrm{pH}$ color classification to obtain an accurate $\mathrm{pH}$ value. In this system, there are 14 classifications, namely $\mathrm{pH} 1-\mathrm{pH} 14$. In this system, testing is carried out with 10 product samples The product samples used in this study are circulating in the market. To display the $\mathrm{pH}$ value and system operation can be seen in figure 4 . The results of the $\mathrm{pH}$ level classification can be seen in table 1 .

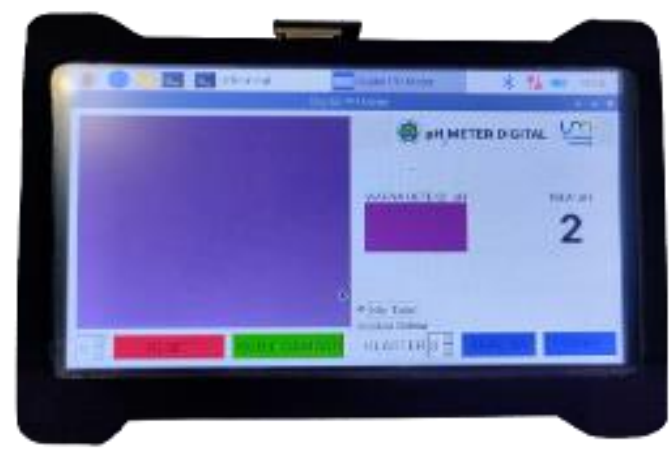

Figure 4 TFT LCD operation system 
Table 1. System trial results

\begin{tabular}{|l|c|c|}
\hline Product Name & PH value & Accuracy (\%) \\
\hline Mineral water brand a & 7 & 88.69 \\
\hline Mineral water brand b & 7 & 94.52 \\
\hline Mineral water brand c & 7 & 91.21 \\
\hline Mineral water brand d & 9 & 97.02 \\
\hline Soft drink & 3 & 94.10 \\
\hline Non-consumed water & 5 & 81.81 \\
\hline Softener & 2 & 80.97 \\
\hline Perfuming clothes & 5 & 87.37 \\
\hline Shampoo brand a & 5 & 80.09 \\
\hline Dishwasher Average & 5 & 91.17 \\
\hline Chemical solutions & 13 & 85.14 \\
\hline \multicolumn{2}{|c|}{ Aver| } & \\
\hline
\end{tabular}

Based on the test results that can be seen in table 1, the system can classify and display the $\mathrm{pH}$ value on the TFT LCD properly. In this study, the average accuracy of the classification system and detecting $\mathrm{pH}$ levels was $88.55 \%$. It can be concluded that the system can detect $\mathrm{pH}$ levels using a biosensor with good accuracy.

\section{CONCLUSION}

The conclusion of this study is to create an image processing system for $\mathrm{pH}$ classification using a biosensor. In this research, the image processing system is carried out by two tests, namely hardware testing and system testing. In hardware testing, the camera can take pictures well because the hardware is designed in a closed manner and the lighting is taken from the LED. While the system test results were carried out with 10 trial samples of mineral water, soft drinks, water, detergent, clothes perfume, and chemical solutions and got an accuracy of $88.55 \%$.

\section{ACKNOWLEDGMENTS}

Research and development of image processing systems for $\mathrm{pH}$ classification using biosensors is funded by PNBP Research Fund, State University of Malang. We would like to thank Dalat University for being helpful in this research.

\section{REFERENCES}

[1] C. Schaude, E. Fröhlich, C. Meindl, J. Attard, B. Binder, and G. J. Mohr, "The development of indicator cotton swabs for the detection of $\mathrm{pH}$ in wounds," Sensors (Switzerland), 2017, doi: 10.3390/s17061365.

[2] J. D. Rios-Mera, J. S. da Silva Pinto, and C. J. Contreras-Castillo, "Effect of ultimate $\mathrm{pH}$ and ageing on thermal denaturation of bovine muscle proteins," Meat Sci., 2017, doi: 10.1016/j.meatsci.2017.04.017.

[3] D. Zhao, Z. Hao, J. Wang, and J. Tao, "Effects of $\mathrm{pH}$ in irrigation water on plant growth and flower quality in herbaceous peony (Paeonia lactiflora Pall.)," Sci. Hortic. (Amsterdam), 2013, doi: 10.1016/j.scienta.2013.02.023.

[4] T. Bhardwaj, "Review on Biosensor Technologies," Int. J. Adv. Res. Eng. Technol., 2015.

[5] A. Amaolo, "The Butterfly Pea Flower as a $\mathrm{pH}$ Indicator,” Int. Scholast. J. Sci., 2017.

[6] B. Wiyantoko and A. Astuti, "Butterfly Pea (Clitoria Ternatea L.) Extract as Indicator of Acid-Base Titration," IJCA (Indonesian J. Chem. Anal., 2020, doi 10.20885/ijca.vol3.iss1.art4.

[7] L. Nur Faezah Syahirah et al., "A comparative analysis of clitoria ternatea linn. (Butterfly pea) flower extract as natural liquid $\mathrm{pH}$ indicator and natural pH paper," Dhaka Univ. J. Pharm. Sci., 2018, doi: 10.3329/dujps.v17i1.37125.

[8] R. Abdullah, P. M. Lee, and K. H. Lee, "Multiple color and $\mathrm{pH}$ stability of floral anthocyanin extract: Clitoria ternatea," in CSSR 2010 - 2010 International Conference on Science and Social Research, 2010, doi: 10.1109/CSSR.2010.5773778.

[9] N. M. Saptarini, D. Suryasaputra, and H. Nurmalia, "Application of Butterfly Pea ( Clitoria ternatea Linn ) extract as an indicator of acid-base titration," Journalof Chem. Pharm. Res., 2015.

[10] S. Phetnuam and T. Yingthawornsuk, "Classfication of Categorized KMUTT-BKT's Landscape Images Using RGB Color Feature," in Proceedings - 14th International Conference on Signal Image Technology and Internet Based Systems, SITIS 2018, 2018, doi: 10.1109/SITIS.2018.00057. 
[11] W. Srigul, P. Inrawong, and M. Kupimai, "Plastic classification base on correlation of RGB color," in 2016 13th International Conference on Electrical Engineering/Electronics, Computer, Telecommunications and Information Technology, ECTI-CON 2016, 2016, doi: 10.1109/ECTICon.2016.7561304.

[12] R. P. Salunkhe and A. A. Patil, "Image processing for mango ripening stage detection: RGB and HSV method," in Proceedings of 2015 3rd International Conference on Image Information Processing, ICIIP 2015, 2016, doi: 10.1109/ICIIP.2015.7414796.

[13] K. Hafidh, I. Muhimmah, and L. Rosita, "Pemrosesan Citra Digital dalam Klasifikasi Hasil Urinalisis Menggunakan Kamera
Smartphone," J. Inform. dan Rekayasa Elektron., 2019, doi: 10.36595/jire.v2i1.70.

[14] Raspberry Pi, "Raspberry Pi 4 Model B," Http://Es.Rs-Online.Com/. 2019.

[15] H. Muchtar and R. Apriadi, "Implementasi Pengenalan Wajah Pada Sistem Penguncian Rumah Dengan Metode Template Matching Menggunakan Open Source Computer Vision Library (Opencv)," Resist. (elektRonika kEndali Telekomun. tenaga List. kOmputeR), 2019, doi: 10.24853/resistor.2.1.39-42.

[16] R. F. Rahmat et al., "Automated color classification of urine dipstick image in urine examination," in Journal of Physics: Conference Series, 2018, doi: 10.1088/17426596/978/1/012008. 